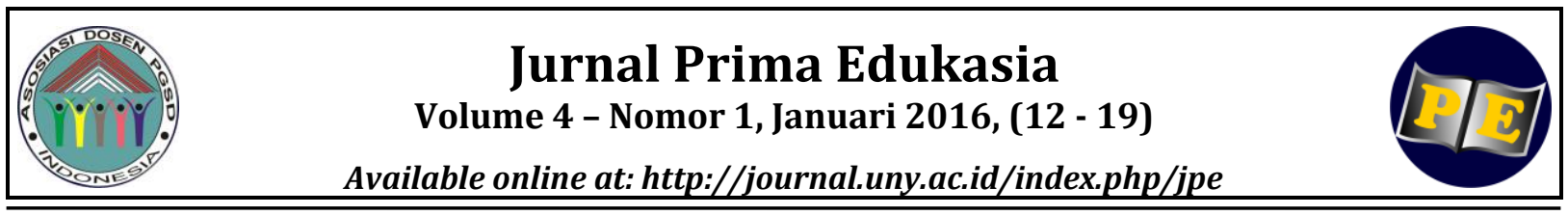

\title{
PERBEDAAN PRESTASI BELAJAR MATEMATIKA SISWA DITINJAU DARI GAYA BELAJAR DAN MODEL PEMBELAJARAN
}

\author{
Alimah Amin ${ }^{1)}$, Siti Partini Suardiman ${ }^{2)}$ \\ ${ }^{1}$ Program Studi Pendidikan Dasar, Program Pascasarjana, Universitas Negeri Yogyakarta. Jalan \\ Colombo No.1, Karangmalang, Yogyakarta 55281, Indonesia \\ ${ }^{2}$ Program Studi Manajemen Pendidikan, Program Pascasarjana, Universitas Ahmad Dahlan \\ Yogyakarta. Jalan Kapas 9 Semaki, Umbulharjo, Yogyakarta 55166, Indonesia \\ Email: ${ }^{1}$ alimahamin@yahoo.co.id, ${ }^{2}$ sitipartini@yahoo.com
}

\begin{abstract}
Abstrak
Penelitian ini bertujuan untuk: (1) mengetahui perbedaan prestasi belajar matematika siswa antara siswa dengan gaya belajar auditorial, visual, dan kinestetik, dan siswa yang memperoleh pembelajaran TGT dan NHT, (2) mengetahui mana yang lebih baik prestasi belajar matematika siswa dengan menggunakan TGT atau NHT.Sampel dari enam Sekolah Dasar (SD) yang terdiri atas kelas IV sebanyak 92 siswa ditentukan dengan cluster random sampling. Pengumpulan dara dilakukan dengan menggunakan angket gaya belajar dan tes prestasi belajar. Teknik analisis data yang digunakan adalah statistik deskriptif, one way anova, uji independent $t$ test.Hasil penelitian ini menunjukkan bahwa: (1) tidak terdapat perbedaan prestasi belajar matematika antara siswa dengan gaya belajar auditorial, visual, dan kinestetik pada pembelajaran TGT dan NHT, serta ada perbedaan prestasi belajar matematika siswa antara siswa yang memperoleh pembelajaran TGT dan siswa yang memperoleh pembelajaran NHT, (2) prestasi belajar matematika dengan model pembelajaran TGT lebih baik dari pada model pembelajaran NHT. Siswa SD masih senang bermain, sehingga tidak dominan dengan satu gaya belajar. Pembelajaran TGT bisa meningkatkan prestasi belajar matematika siswa karena siswa dituntut lebih aktif mulai dari diskusi sampai turnamen.
\end{abstract}

Kata kunci: prestasi belajar, gaya belajar, TGT, NHT

\section{THE DIFFERENCES IN MATHEMATICS LEARNING ACHIEVEMENT SEEN FROM LEARNING STYLES AND LEARNING MODEL}

\begin{abstract}
This study aims to: (1) know the difference between mathematics learning achievement of students with auditory, visual, and kinesthetic learning styles and receiving TGT and NHT learning (2) know which one has higher mathematics achievement between students who is TGT or NHT.92 students of grade IV from 6 elementary schools were taken as samples using cluster random sampling technique. Data collection was done by using learning style questionnaires and learning achievement tests. The data analysis technique used was statistics descriptive, one way anova, independent $t$ test.The results of this study indicate that: (1) there is no difference in mathematics achievement between students with auditory, visual, and kinesthetic learning style, (2) the are differences in mathematics achievement between students who received TGT learning and students who received NHT, (3) students with TGT learning model have higher mathematics learning achievement than those with NHT. Elementary school students still love to play, so they are not dominant with one learning style. TGT learning can improve students" mathematics achievement as students demanded to be active from the discussion to the tournament.
\end{abstract}

Keywords: achievement, learning styles, TGT, NHT

How to Cite: Amin, A., \& Suardiman, S. (2016). Perbedaan prestasi belajar matematika siswa ditinjau dari gaya belajar dan model pembelajaran. Jurnal Prima Edukasia, 4(1), 12 - 19. Retrieved fromhttp://journal.uny.ac.id/index.php/jpe/article/view/7688 
Jurnal Prima Edukasia, 4 (1), Januari 2016 - 13

Alimah Amin, Siti Partini Suardiman

\section{Pendahuluan}

Mata pelajaran matematika perlu diberikan kepada semua peserta didik mulai dari tingkat sekolah dasar untuk membekali peserta didik dengan kemampuan berpikir logis, analitis, sistematis, kritis, dan kreatif, serta kemampuan bekerja sama. Kemampuan tersebut diperlukan agar peserta didik dapat memiliki kemampuan memperoleh, mengelola, dan memanfaatkan informasi untuk bertahan hidup pada keadaan yang selalu berubah, tidak pasti, dan kompetitif.

Di dalam pembelajaran, prestasi belajar merupakan bagian yang tidak dapat dipisahkan karena melalui prestasi belajar inilah orang dapat melihat pencapaian individu melalui proses belajarnya. "learning is enduring change in behavior, or in the capacity to behave in a given fashion, which results from practice or other from of experience". Dari pernyataan tersebut terdapat dua komponen penting dalam belajar: pertama, bahwa belajar merupakan perubahan perilaku atau dalam kapasitas tertentu menetap. Kedua, perubahan perilaku dalam belajar diperoleh melalui hasil praktik dalam bentuk pengalaman lain (Schunk, 2009, p.2).

Piaget menyatakan bahwa proses pembentukan pengetahuan itu terjadi apabila seseorang mengubah atau mengembangkan skema yang dimiliki dalam berhadapan dengan tantangan, rangsangan, atau persoalan. Dengan proses asimilasi dan akomodasi itu, pengetahuan seseorang dikembangkan dan dimajukan (Suparno, 2005, p.123).

Matematika pada hakekatnya adalah ilmu, cara berpikir, metode, seni, alat untuk mendeskripsikan dan memecahkan masalah, bahkan bisa dikategorikan sebagai bahasa sebab matematika mampu mengkomunikasikan sebuah gagasan abstrak ke dalam konsep-konsep logika simbolik yang dituangkan dalam modelmodel matematika (Aningsih, 2012, p.121)

Prestasi belajar atau hasil belajar akan tampak pada setiap perubahan pada aspekaspek pengetahuan, pemahaman, kebiasaan, keterampilan, apresiasi, emosional, hubungan sosial, jasmani, budi pekerti (etika), sikap dan lain-lain. (Hamalik, 2013, p.38). Selanjutnya dinyatakan prestasi belajar adalah sebagai suatu petunjuk mengenai taraf kemampuan individu dalam melakukan proses belajar.

"A primary science methods classroom was conceived, designed, and developed for preserviceand inservice teachers. Just as science educators believe that students learn best by consructing their knowledge of the natural world with the aid of a teacher and colleagues, science educators also believe that preservice and inservice teachers should learn in a collaborative and constructivist environment". Metode pendidikan dasar di kelas seharusnya dikonsep, didesain, dan dikembangkan oleh guru. Namun belajar yag paling baik bagi siswa dengan mengkonstruksi pengetahuannya dengan bantuan guru dan sekolah, ahli pendidikan juga menyatakan bahwa belajar itu seharusnya dalam lingkungan kolaboratif dan konstruktif (William \& Jacson, 2006, p.25).

Dari berbagai pendapat tersebut dapat disimpulkan bahwa prestasi belajar matematika adalah hasil yang diperoleh dari serangkaian usaha dalam pembelajaran matematika untuk memperoleh pengalaman atau pengetahuan baru. Prestasi belajar matematika dapat berupa penguasaan terhadap sejumlah materi matematika melalui tes (kognitif) maupun perubahan sikap (afektif).

faktor-faktor yang mempengaruhi belajar banyak jenisnya, tetapi dapat digolongkan menjadi dua golongan saja, yaitu faktor intern dan faktor ekstern. Faktor intern adalah faktor yang ada dalam diri individu yang sedang belajar yaitu terdiri atas; faktor jasmaniah (kesehatan dan cacat tubuh), faktor psikologis (intelegensia, perhatian. Minat, bakat, motivasi), dan faktor kelelahan. Sedangkan faktor ekstern adalah faktor yang ada di luar individu terdiri atas; faktor keluarga, faktor sekolah, dan faktor masyarakat (Slameto, 2003, p.56).

Faktor guru dan cara mengajarnya merupakan faktor yang penting. Bagaimana sikap dan kepribadian guru, tinggi rendahnya pengetahuan yang dimiliki guru, dan bagaimana cara guru mengajarkan pengetahuan itu kepada anak didiknya, turut menentukan bagaimana prestasi belajar yang dapat dicapai anak (Purwanto, 2013, p.104)

"In elementary and secondary, learning and achievement are both valuable goals. For each individual student, attainment of these goals depends on the complex interrelationships among a number of variables. Including student background characteristics, prior learning, motivation, teacher characteristics, instructional quality, classroom environment, parental support, and a host of other factors.

Di sekolah dasar, menengah belajar, dan prestasi keduanya adalah tujuan berharga. Untuk masing-masing siswa, pencapaian tujuan ini tergantung pada timbal balik yang kompleks 
Jurnal Prima Edukasia, 4 (1), Januari 2016 - 14

Alimah Amin, Siti Partini Suardiman

antra sejumlah variabel, termasuk karakteristik latar belakang siswa, sebelum belajar, motivasi, karakteristik guru, kualitas pembelajaran, lingkungan kelas, dukungan orang tua, dan sjumlah faktor lainnya.

Model pembelajaran kooperatif bermacam-macam ada TPS Think Pair and Share (TPS), Contextual Teaching and Learning (CTL), Numbered Head Together (NHT), Student Team Achivement Division (STAD), Team Games Tournament (TGT) dan sebagainya. Dalam penelitian ini yang akan digunakan adalah Team Games Tournament (TGT) dan Numbered Head Together (NHT).

Pembelajaran Teams Games Tournament (TGT)merupakan pembelajaran yang menggabungkan kegiatan belajar kelompok dengan kompetisi kelompok yang pelaksanaannya menggunakan permainan maupun turnamen. Permainan pada TGT lebih meningkatkan kesan positif karena pada permainan ini siswa lebih banyak membutuhkan energi untuk berpikir mendapatkan point untuk kelompoknya.

Pembelajaran TGT terdapat lima komponen yaitu: presentasi kelas, tim, game/permainan, turnamen/pertandingan dan penghargaan tim. Pada pembelajaran ini terdapat permainan yang dapat membuat siswa lebih bertanggung jawab, bekerja sama dalam tim, dan terdapat persaingan sehat dalam turnamen. (1) Presentasi kelas: Presentasi kelas/penyajian materi digunakan guru untuk memperkenalkan materi pelajaran secara langsung dan klasikal. Pada tahap ini guru menjelaskan materi pokok pembelajaran serta memantau pemahaman siswa tentang materi yang disampaikan. Siswa harus benar-benar memperhatikan dan memahami materi yang disampaikan guru, karena akan membantu siswa bekerja lebih baik pada saat kerja kelompok dan pada saat melakukan game karena skor game akan menentukan skor kelompok. (2) Tim: Tim terdiri atas empat atau lima siswa yang mewakili seluruh bagian dari kelas dalam hal prestasi akademik, jenis kelamin, ras, dan etnis. Fungsi utama dari tim adalah memastikan anggota tim benar-benar belajar. Pada kegiatan kelompok ini siswa benarbenar mempelajari materi yang disajikan, sekaligus membantu teman sekelompok yang belum menguasai materi tersebut. Kemudian siswa mengerjakan lembar kegiatan yang diberikan guru. Lembar kegiatan itu harus dikerjakan dengan berdiskusi didalam kelompok. Jika ada pertanyaan yang belum dijawab dalam kelompok maka dapat ditanyakan kepada guru.
Tim merupakan komponen terpenting dalam pembelajaran kooperatif tipe TGT. Tekanannya adalah anggota tim melakukan yang terbaik untuk tim dan tim juga melakukan yang terbaik untuk setiap anggotanya dalam meningkatkan akademik. Selain itu, tim juga memberikan perhatian dan penghargaan yang seimbang/sama terhadap setiap anggota tim, sehingga timbul rasa dihargai dan adanya penerimaan siswa dalam timnya. (3) Game/Permainan: Game/ permainan terdiri atas pertanyaan-pertanyaan yang relevan dengan materi pada presentasi kelas dan pelaksanaan kegitan/tim. Permainan ini dirancang untuk menguji pengetahuan yang dicapai oleh siswa. Permainan dilakukan oleh tiga/empat orang yang berkemampuan sama/ setara dan masing-masing mewakili tim yang berbeda. Kelengkapan permainan biasanya berupa pertanyaan atau soal dan kunci jawaban bernomor serta kartu bernomor. Siswa yang mendapat giliran mengambil kartu bernomor, membaca pertanyaan dari nomor yang terambil dan berusaha menjawab pertayaan. (4) Turnamen: Turnamen adalah sebuah struktur dimana permainan berlangsung. Turnamen dilaksanakan pada akhir minggu atau unit setelah guru memberikan presentasi kelas/penyajian materi dan setiap tim sudah melaksanakan kerja kelompok terhadap lembar kegiatan siswa. Turnamen terdiri atas tiga/empat siswa yang berkemampuan sama/setara dan masing-masing mewakili tim yang berbeda bersaing dalam menjawab soal. Persaingan ini memungkinkan siswa dari semua tingkatan kemampuan menyumbangkan nilai maksimum bagi timnya. Setelah turnamen, para siswa akan bertukar meja tergantung pada skor mereka pada turnamen terakhir. Pemenang pada setiap meja naik ke meja berikutnya yang lebih tinggi (misal dari meja 4 ke meja 3), skor tertinggi kedua tetap tinggal pada meja yang sama dan skor yang paling rendah diturunkan. Dengan cara ini, jika pada awalnya siswa sudah salah ditempatkan, maka untuk seterusnya mereka akan terus naik atau ditunkan sampai mereka mencapai tingkat kinerja yang sesungguhnya, (5) Penghargaan Tim: Tim-tim yang berhasil mendapatkan nilai rata-rata yang melebihi criteria tertentu diberi penghargaan berupa sertifikat atau penghargaan lain.

Jadi dapat disimpulkan Teams Games Tournament (TGT) adalah pembelajaran yang dimulai dengan diskusi kelompok dan permainan serta turnamen untuk mengukur kemampuan siswa dalam memahami pelajaran, disamping 
Jurnal Prima Edukasia, 4 (1), Januari 2016 - 15

Alimah Amin, Siti Partini Suardiman

itu pembelajaran ini dapat menumbuhkan tanggung jawab, kerja sama, persaingan sehat dan keterlibatan belajar.

Pembelajaran Numbered head Together (NHT) merupakan pembelajaran kooperatif yang sederhana. Dikatakan demikian karena pada langkah ke 2 dari langkah-langkah pembelajaran kooperatif tipe NHT yaitu adanya penyajian informasi atau materi pelajaran. Perbedaan tipe NHT dengan pembelajaran konvensional adalah dibentuknya kelompok dan setiap siswa kemungkinan menjelaskan kembali hasil diskusi kelompok mereka.

Numbered Head Together (NHT) merupakan variansi dari diskusi kelompok. Tujuan NHT adalah memberi kesempatan kepada siswa untuk saling berbagi gagasan dan mempertimbangkan jawaban yang paling tepat. Selain itu meningkatkan kerja sama siswa, NHT juga bisa diterapkan untuk semua mata pelajaran dan tingkatan kelas. Pada pembelajaran NHT terdapat kerja sama tim, semua siswa dalam tim harus menguasai materi yang disampaikan guru. Pada pembelajaran NHT siswa yang mempunyai kemampuan tinggi harus membantu siswa yang mempuyai kemampuan di bawahnya. Pada pembelajaran ini semua siswa bertanggung jawab kepada timnya masingmasing. tahapan-tahapan pelaksanaan NHT pada hakikatnya hampir sama dengan diskusi kelompok, yang rinciannya adalah sebagai berikut: (1) Siswa dibagi ke dalam kelompok-kelompok, (2) Masing-masing siswa dalam kelompok diberi nomor, (3) Guru memberi tugas/pertanyaan pada masing-masing kelompok untuk mengerjakannya, (4) Setiap kelompok mulai berdiskusi untuk menenmukan jawaban yang dianggap paling tepat dan memastikan semua anggota kelompok mengetahui jawaban tersebut, (5) Guru memanggil salah satu nomor secara acak, (6) Siswa dengan nomor yang dipanggil mempresentasikan jawaban dari hasil diskusi kelompok mereka. (Huda, 2013, pp.203-204).

Jadi Numbered Head Together adalah pembelajaran yang dikembangkan melalui diskusi, pembelajaran ini juga mendorong siswa untuk meningkatkan semangat kerja sama antar siswa.

Hasil penelitian menunujukkan keaktifan belajar dan prestasi belajar siswa yang mengikuti model pembelajaran kooperatif tipe NHT berbantuan senam otak lebih baik dari pada siswa yang mengikuti pembelajaran konvensional. (Sukmayasa, 2013, p.103-121).
Di SD Kecamatan Banjarsari belum banyak guru yang mengajar dengan berbagai model pembelajaran dikarenakan waktu yang terbatas dalam menyelesaikan semua standar kompetensi dalam satu semester. Kebanyakan guru masih mengajar dengan konvensional yaitu guru menerangkan di papan tulis dan siswa bertanya apabila ada kesulitan. Cara mengajar guru secara konvensional meyebabkan siswa tidak aktif karena siswa hanya duduk dan memperhatikan, tanpa harus mencari tahu apa yang akan diajarkan oleh guru. Siswa tidak termotivasi untuk mencari tahu apa yang guru ajarkan karena guru nanti akan menjawab pertanyaan jika siswa tidak bisa.

Prestasi belajar matematika yang memuaskan ditentukan juga oleh gaya belajar siswa. Gaya belajar adalah salah satu aspek yang perlu mendapat perhatian. Gaya belajar merupakan cara termudah yang dimiliki oleh individu dalam menyerap, mengatur dan mengolah informasi yang diterima. Gaya belajar yang sesuai adalah kunci keberhasilan seseorang dalam belajar. Oleh karena itu, dalam kegiatan belajar, siswa sangat perlu dibantu dan diarahkan untuk mengenali gaya belajar yang sesuai dengan dirinya sehingga tujuan pembelajaran dapat dicapai secara efektif. Kemampuan seseorang untuk memahami dan menyerap pelajaran sudah pasti berbeda tingkatnya. Ada yang cepat, sedang dan ada pula yang sangat lambat. Karenanya, mereka seringkali harus menempuh cara berbeda untuk bisa memahami sebuah informasi atau pelajaran yang sama. Sebagian siswa lebih suka guru mereka mengajar dengan cara menuliskan segalanya di papan tulis. Dengan begitu mereka bisa membaca untuk kemudian mencoba memahaminya. Tapi, sebagian siswa lain lebih suka guru mereka mengajar dengan cara menyampaikannya secara lisan dan mereka mendengarkan untuk bisa memahaminya. Sementara itu, ada siswa yang lebih suka membentuk kelompok kecil untuk mendiskusikan pertanyaan yang menyangkut pelajaran tersebut. Cara lain yang juga kerap disukai banyak siswa adalah model belajar yang menempatkan guru tak ubahnya seorang penceramah. Guru diharapkan bercerita panjang lebar tentang beragam teori dengan segudang ilustrasinya, sementara para siswa mendengarkan sambil menggambarkan isi ceramah itu dalam bentuk yang hanya mereka pahami sendiri.

Gaya belajar siswa memiliki peranan sangat penting dalam belajar matematika, karena gaya belajar matematika merupakan ciri 
Jurnal Prima Edukasia, 4 (1), Januari 2016 - 16

Alimah Amin, Siti Partini Suardiman

khas yang konsisten yang dilakukan siswa dalam menyerap informasi. Gaya belajar dikelompokkan menjadi tiga yaitu auditorial, visual, dan kinestetik. Pelajar visual belajar melalui apa yang merka lihat, pelajar auditorial melakukannya melalui apa yang mereka dengar, dan pelajar kinestetik lewat gerak dan sentuhan. Walaupun ketiga modalitas ini ada dalam diri seorang siswa, kebanyakan cenderung pada salah satu diantara ketinganya (Deporter \& Hernacki, 2000, p.111-112).

Siswa dengan gaya belajar visual lebih suka belajar dengan cara melihat siswa dengan gaya belajar visual ini mempunyai karakteristik positif diantaranya: mudah mengingat dengan asosiasi visual, pembaca yang cepat dan tekun, dapat duduk dengan tenang disituasi yang ramai dan bising tanpa merasa terganggu. Siswa dengan gaya belajar auditorial lebih suka belajar dengan cara mendengar. Siswa dengan gaya belajar auditorial mampu megingat dengan baik materi yang dijelaskan guru maupun yang didiskusikan di kelas atau dalam kelompok. Siswa dengan gaya belajar kinestetik lebih suka belajar dengan cara bergerak/praktik dan menyentuh dengan tangan. Siswa dengan gaya belajar ini biasanya suka belajar manipulasi (mengembangkan data dan fakta) suka belajar dengan menggunakan objek yang nyata sebagai alat bantu. Dengan demikian, perbedaan gaya belajar matematika mengakibatkan perbedaan prestasi belajar siswa.

Hasil penelitian menunjukkan mengemukakan ada perbedaan yang sigifikan yang ditemukan dalam kelompok perawat dan guru, serta saat perewat dan guru diuji untuk membantu para ahli. Implikasi dalam penelitian ini adalah kebijakan bagaimana seorang perawat tidak sekedar dididik tetapi juga bagaimana mereka direkrut berdasarkan gaya belajar sehingga akan menghasilkan prestasi yang tinggi (DeShields, 2005).

Hasil penelitian menunjukkan (1) prestasi belajar matematika siswa yang diberikan pendekatan kontruktivisme lebih baik daripada pembelajaran konvensional, (2) siswa dengan gaya belajar visual lebih baik prestasi belajar matematikanya dibandingkan dengan gaya belajar kinestetik, tetapi tidak lebih baik daripada auditorial dan siswa dengan gaya belajar auditorial lebih baik prestasi belajar matematikanya dibandingkan dengan siswa dengan gaya belajar kinestetik, (3) perbedaan prestasi belajar matematika siswa antara siswa yang diberikan pendekatan pembelajaran kontruk- tivisme dan pembelajaran konvensional selalu sama (konsisten) untuk tiap-tiap gaya belajar demikian juga siswa dengan gaya belajar visual, auditorial, dan kinestetik terhadap pendekatan pembelajaran (Endang, p.26).

Tujuan penelitian ini adalah mengetahui perbedaan prestasi belajar matematika siswa antara gaya belajar auditorial, visual, dan kinestetik, dan siswa yang memperoleh pembelajaran Numbered Head Together (NHT) dan Teams Games Tournament (TGT) serta mengetahui mana yang lebih tinggi antara siswa dengan pembelajaran NHT atau TGT.

\section{Metode}

Jenis Penelitian Penelitian ini menggunakan pendekatan kuantitatif komparatif. yaitu membandingkan prestasi belajar siswa sekolah dasar yang menggunakan model pembelajaran TGT dan NHT, selain itu membandingkan prestasi belajar siswa sekolah dasar berdasarkan gaya belajar siswa. Penelitian ini tidak melakukan pretest (pengumpulan data awal) dan post-test (pengumpulan data akhir) melainkan sekali mengumpulkan data, yang disebut penelitian one shoot (sekali tembak).

\section{Tempat dan Waktu Penelitian}

Penelitian ini dilaksanakan di sekolah dasar di Kecamatan Banjarsari Surakarta. Waktu pelaksanaan penelitian ini dimulai pada bulan Maret 2014 sampai dengan bulan September 2014.

\section{Subyek Penelitian}

Populasi penelitian ini adalah seluruh siswa kelas IV SD Kecamatan Banjarsari. Sampel penelitian ditentukan dengan menggunakan teknik cluster random sampling yaitu teknik memilih sebuah sampel dari kelompok-kelompok unit yang kecil. Teknik pengambilan sampel secara cluster random sampling. Teknik sampling ini digunakan melalui dua tahap yaitu tahap pertama menentukan sampel di setiap sekolah, yang kedua menentukan kelas atau siswa yang ada disekolah tersebut. Sampel dalam penelitian ini akan diambil siswa kelas IV SD Kecamatan Banjarsari Surakarta yang berjumlah 84 siswa. Alasan dengan pertimbangan tidak berbeda dalam tingkatan atau strata, tetapi masing-masing mempunyai karakteristik sendiri-sendiri. 
Jurnal Prima Edukasia, 4 (1), Januari 2016 - 17

Alimah Amin, Siti Partini Suardiman

Pengumpulan Data

Pengumpulan data menggunakan angket gaya belajar dan soal prestasi belajar. Angket adalah sebuah daftar pertanyaan yang harus diisi oleh orang yang akan diukur (responden) (Arikunto, 2002, p.28). Angket gaya belajar berisi pertanyaan-pertanyaan yang berhubungan dengan gaya belajar siswa. Gaya belajar meliputi auditorial, visual dan kinestetik. Berdasarkan ciri-ciri gaya belajar yang diteliti dalam penelitian sebagai berikut: (1) gaya belajar auditorial, cirinya sebagai berikut: (a) mudah terganggu oleh keributan (b) belajar dengan mendengarkan dan mengingat apa yang didiskusikan dari pada menuliskannya, (c) suka berbicara, suka berdiskusi, dan menjelaskan sesuatu panjang lebar mempunyai masalah dengan pekerjaan-pekerjaan yang melibatkan visualisasi, (d) suka berbicara, suka berdiskusi, dan menjelaskan sesuatu panjang lebar, (2) gaya belajar visual, cirinya sebagai berikut: (a) teliti terhadap detail, (b) mempunyai masalah instruksi, (c) mengingat apa yang dilihat dari pada didengar, (d) sering kehilangan konsentrasi, (3) gaya belajar kinestetik, cirinya sebagai berikut: (a) banyak gerak, (b) menggunakan isyarat tubuh, (c) belajar menggunakan manipulasi dan praktek, (e) berdiri dekat ketika berbicara dengan orang

Skor angket pada penelitian ini didasarkan pada gaya belajar matematika yaitu dengan cara memberikan skor 5 untuk jawaban "selalu", nilai 4 untuk jawaban "sering",nilai 3 untuk jawaban "kadang-kadang", nilai 2 untuk jawaban "jarang" dan nilai 1 untuk jawaban "tidak pernah". Kecenderungan gaya belajar siswa ditentukan dari sejumlah skor tertinggi untuk masing-masing gaya belajar siswa yang diperoleh dari jawaban siswa. Jika terdapat gaya belajar siswa yang memiliki dua skor atau lebih yang sama maka kecenderungan gaya belajar siswa ditentukan dengan melihat dari jumlah jawaban "selalu" atau "sering" yang lebih banyak diberikan siswa.

Tes prestasi belajar berupa tes objektif/pilihan ganda pada standar kompetensi memahami dan menggunakan faktor dan kelipatan dalam pemecahan masalah. Jawaban dari setiap pertanyaan jika benar 1 dan jika salah 0 .

\section{Teknik Analisis Data}

Teknik analisis data yang digunakan pada penelitian ini adalah analisis deskriptif dan analisis statistik parametrik. Pada analisis deskriptif menggambarkan data dalam bentuk frekuensi masing-masing variabel. Pada analisis statistic parametrik menggunakan uji hipotesis yang harus memenuhi syarat normalitas dan homogenitas. Pada gaya belajar uji hipotesisnya menggunakan One Way Anova. Untuk mempermudah menggunakan SPSS 15, dengan hipotesis:

$\mathrm{H}_{0}$ : tidak ada perbedaan prestasi belajar antara gaya belajar auditorial, visual dan kinestetik.

$\mathrm{H}_{\mathrm{a}}$ : ada perbedaan prestasi belajar antara gaya belajar auditorial, visual dan kinestetik.

Adapun kriteria untuk menolak $\mathrm{H}_{0}$ berdasarkan jika nilai signifikansi kurang dari $\alpha(0,05)$. Sedangkan untuk mengetahui perbedaan antara prestasi belajar antara siswa NHT dan TGT menggunakan independent t-test dengan berbantuan SPSS 15, dengan hipotesis:

$\mathrm{H}_{\mathrm{a}}$ : terdapat perbedaan prestasi belajar matematika yang memperoleh model pembelajaran TGT dan NHT

$\mathrm{H}_{0}$ : tidak terdapat perbedaan prestasi belajar matematika yang memperoleh model pembelajaran TGT dan NHT.

\section{Hasil dan Pembahasan}

Data variable gaya belajar menggunakan angket gaya belajar siswa dengan jumlah pertanyaan masing-masing 13 butir untuk setiap tipe gaya belajar auditorial, visual, dan kinestetik. Skor minimal tiap butir 1 dan skor maksimal 5, karena terdapat lima alternatif jawaban.

Distribusi data variabel gaya belajar pada siswa TGT disajikan dalam tabel dibawah ini:

Tabel 1. Distribusi Gaya Belajar Siswa TGT

\begin{tabular}{cccc}
\hline & Auditorial & Visual & Kinestetik \\
\hline Maksimum & 43 & 48 & 43 \\
Minimum & 21 & 21 & 21 \\
Rata-rata & 32,48 & 39,03 & 30,73 \\
Jumlah Siswa & 11 & 74 & 5 \\
Jumlah \% & 12,22 & 82,22 & 47,77 \\
\hline
\end{tabular}

Berdasarkan uraian, dapat diketahui bahwa siswa yang medapatkan pembelajaran Teams Games Tournament (TGT) memiliki gaya belajar visual lebih banyak dibandingkan gaya belajar auditorial dan kinestetik, yaitu sebesar 4 siswa atau 82,22\% lebih tinggi dibandingkan auditorial sebesar 11 siswa atau $12,22 \%$ dan 5 siswa atau kinestetik 47,77\%.

Distribusi data variabel gaya belajar pada siswa TGT disajikan dalam Tabel 2: 
Jurnal Prima Edukasia, 4 (1), Januari 2016 - 18

Alimah Amin, Siti Partini Suardiman

Tabel 2. Distribusi Gaya Belajar Siswa NHT

\begin{tabular}{cccc}
\hline & Auditorial & Visual & Kinestetik \\
\hline Maksimum & 55 & 81 & 54 \\
Minimum & 23 & 28 & 21 \\
Rata-rata & 36,35 & 44,15 & 33,15 \\
Jumlah Siswa & 15 & 68 & 9 \\
Jumlah \% & 16,30 & 79,91 & 10 \\
\hline
\end{tabular}

Berdasarkan uraian, dapat diketahui bahwa pada pembelajaran Numbered Head Together (NHT) siswa yang memiliki gaya belajar visual lebih banyak dibandingkan gaya belajar auditorial dan kinestetik., yaitu 68 siswa atau $79,91 \%$ lebih tinggi dari auditorial 15 siswa tau $16,30 \%$ dan kinestetik 9 siswa tau $10 \%$.

Deskripsi prestasi belajar matematika TGT dan NHT diperoleh menggunakan angket gaya belajar yang berjumlah 20 butir, dengan jawaban benar diberi skor 1 dan jawaban salah diberi skor 0. Distribusi variabel prestasi belajar pada siswa TGT seperti pada Tabel 3:

Tabel 3. Distribusi Prestasi Belajar Matematika Siswa TGT dan NHT

\begin{tabular}{ccc}
\hline & TGT & NHT \\
\hline Maksimum & 100 & 95 \\
Minimum & 70 & 65 \\
Rata-rata & 82,28 & 79,24 \\
Median & 80,00 & 80,00 \\
Modus & 80 & 80 \\
Standar Deviasi & 6,752 & 6,791 \\
Jumlah Siswa & 92 & 90 \\
\hline
\end{tabular}

Rata-rata prestasi belajar siswa TGT adalah 82,28 dari 90 siswa sedangkan prestasi belajar siswa NHT lebih rendah yaitu 79,24.

Untuk menguji hipotesis gaya belajar menggunakan anava. Pada pembelajaran TGT nilai signifikansi 0,743 . Nilai sig $0,743>0,05$ jadi $\mathrm{H}_{0}$ ditolak, artinya tidak perbedaan antara gaya belajar auditorial, visual, dan kinestetik pada siswa dengan model belajar TGT.

Pada pembelajaran NHT nilai sig $0,076>0,05$, jadi $\mathrm{H}_{0}$ ditolak, artinya tidak perbedaan antara gaya belajar auditorial, visual, dan kinestetik pada siswa dengan model pembelajaran NHT.

Pada prestasi belajar matematika yang dihitung dengan uji independent t-test, diketahui nilai mean Prestasi belajar siswa TGT sebesar 82,28 dan nilai mean prestasi belajar siswa NHT sebesar 79,24 ini berarti bahwa skor prestasi belajar matematika siswa TGT lebih tinggi daripada skor prestasi belajar matematika siswa NHT. Hasil selengkapnya dapat dilihat pada tabel berikut:
Tabel 4. Hasil Uji Perbandingan Gaya Belajar

\begin{tabular}{llllrc}
\hline & model & N & Mean & $\begin{array}{c}\text { Std. } \\
\text { Deviation }\end{array}$ & $\begin{array}{c}\text { Std. } \\
\text { Error } \\
\text { Mean }\end{array}$ \\
\hline TgtNht & Tgt & 90 & 82,28 & 6,752 & 0,712 \\
& Nht & 92 & 79,24 & 6,791 & 0,708 \\
\hline
\end{tabular}

Nilai uji Lavene menunjukkan sig 0.904 lebih besar dari 0,05 maka $\mathrm{H}_{0}$ diterima. Hasil uji tersebut nilai $\mathrm{t}$ hitung $>\mathrm{t}$ tabel $(3,027>1,960)$ dan $\mathrm{P}$ value $(0,003<0,05)$ maka $\mathrm{H}_{0}$ ditolak, artinya ada perbedaan prestasi belajar matematika antara model pembelajaran TGT dan NHT. Hasil selengkapnya dapat dilihat pada Tabel 5 berikut:

Tabel 5. Hasil Uji independent T-Test

\begin{tabular}{cccccc}
\hline & \multicolumn{4}{c}{ Uji Lavene } \\
\cline { 2 - 6 } & Sig & $\begin{array}{c}\text { t- } \\
\text { hitung }\end{array}$ & $\begin{array}{c}\mathbf{t} \\
\text { tabel }\end{array}$ & $\begin{array}{c}\mathbf{P} \\
\text { value }\end{array}$ & $\begin{array}{c}\text { Mean } \\
\text { difference }\end{array}$ \\
\hline $\begin{array}{c}\text { Equal } \\
\text { Variance }\end{array}$ & 0,904 & 3,027 & 1,960 & 0,003 & 3,039 \\
assumed & & & & & \\
\hline
\end{tabular}

Jadi dalam penelitian ini tidak ada perbedaan prestasi belajar matematika siswa sekolah dasar antara siswa yang mempunyai gaya belajar auditorial, visual, maupun kinestetik. Rata-rata setiap siswa mempunyai gaya belajar yang berubah-ubah jadi gaya belajar tidak bisa dijadikan sebagai tolak ukur perbedaan prestasi siswa. Tidak ada perbedaan prestasi belajar matematika siswa antara siswa yang memiliki gaya belajar auditorial, visual, dan kinestetik, hal ini disebabkan oleh: (a) Siswa sekolah dasar belum memiliki gaya belajar yang dominan dikarenakan siswa sekolah dasar masih dominan untuk bermain dibandingkan belajar, (b) Guru mengajar dengan gaya belajar yang berbeda dari siswa sehingga siswa enggan mengikuti pelajaran, yang kedua ada perbedaan prestasi belajar matematika siswa antara siswa yang memperoleh model pembelajaran TGT dan prestasi belajar matematika siswa yang memperoleh model pembelajaran NHT. Hal ini ditunjukkan pada model pembelajaran TGT dan NHT nilai $t_{\text {hitung }}$ lebih besar dari $t_{\text {tabel }}(3,027$ $>1,960)$ sehingga $\mathrm{H}_{0}$ ditolak dan $H_{a}$ diterima. Hal ini disebabkan oleh: (a) Model pembelajaran TGT memiliki aktifitas belajar dengan permainan sehingga memungkinkan siswa dapat belajar lebih rileks disamping menumbuhkan tanggung jawab, kerja sama, persaingan sehat dan keterlibatan belajar. (b) Permainan dengan menggunakan kerja sama TGT lebih meningkatkan kesan positif siswa terhadap 
Jurnal Prima Edukasia, 4 (1), Januari 2016 - 19

Alimah Amin, Siti Partini Suardiman

matematika dibandingkan dengan permainan tanpa kerja sama (permainan individual). (c) Model pembelajaran TGT siswa dituntut aktif untuk banyak kegiatan mulai dari diskusi sampai adanaya turnamen, kegiatan siswa yang banyak inilah yang menuntut siswa lebih memahami dan konsentrasi dalam materi kelipatan faktor dan persekutuan.

\section{Simpulan dan Saran}

Kesimpulan penelitan ini yang pertama tidak ada perbedaan prestasi belajar matematika antara siswa yang mempunyai gaya belajar auditorial, visual, dan kinestetik. Hasil penelitian didapatkan nilai sisgnifikansi 0,743 lebih besar dari 0,05 hal ini mennjukkan hipotesis ditolak. Menurut peneliti periode umur Sekolah Dasar masih senang bermain, belum fokus untuk belajar, sehingga siswa tidak dominan dengan satu gaya belajar saja.

Kesimpulan kedua terdapat perbedaan prestasi belajar siswa yang memperoleh model pembelajaran TGT dan NHT. Hasil penelitian didapatkan nilai mean prestasi siswa pada pembelajaran TGT 82,28 dan pada siswa yang memperoleh model pembelajaran NHT 79,24 ini menunjukkan bahwa prestasi belajar siswa dengan model pembelajaran TGT lebih tinggi dibandingkan dengan siswa yang memperoleh model pembelajaran NHT. Hal ini disebabkan pada model pembelajaran TGT kegiatan siswa lebih banyak dibandingkan kegiatan pada pembelajaran NHT.

Saran yang diberikan peneliti antara lain: (1) kepada guru dalam memberikan pelajaran sebaiknya menggunakan model pembelajaran TGT, hal ini berdasarkan penelitian yang membuktikan prestasi belajar siswa TGT lebih tinggi daripada siswa NHT serta tidak mengabaikan gaya belajar yang berbeda-beda dari setiap siswa. Dari hasil penelitian memang memberikan hasil bahwa prestasi belajar matematika siswa dengan gaya belajar yang berbeda tidak me- miliki perbedaan yang signifikan, (2) untuk penelitian lebih lanjut dalam penggunaan model pembelajaran kooperatif disamping guru menjadi mitra peneliti, perlu untuk disosialisasikan terlebih dahulu kepada siswa bagaimana prosedur penggunaan model pembelajaran kooperatif sehingga penggunaan waktu bisa efisien dan efektifitas pembelajaran dapat tercapai, (3) Untuk peneliti lain yang menggunakan model pembelajaran kooperatif disarankan untuk menggunakan model pembelajaran kooperatif yang memilki kualitas kelayakan sama antara model kooperatif yang dibandingkan sehingga penelitian lebih akurat. (4) untuk peneliti lain, untuk tidak meneliti gaya belajar untuk siswa sekolah dasar, karena siswa sekolah dasar belum memiliki gaya belajar yang dominan. Peneliti lain bias meneliti pada siswa yang tingkatan sekolahnya lebih tinggi.

\section{Daftar Pustaka}

Huda M. (2013). Model-model pengajaran dan pembelajaran. Isu-isu metodis dan Paradigmatis. Malang: Pustaka Pelajar

Hamalik, O. (2007). Kurikulum dan pembelajaran. Jakarta: Bumi Aksara

Suparno, P. (2005). Teori perkembangan kognitif Jean Piaget. Yogyakarta: Kanisius

Purwanto, M.N. (2013). Psikologi pendidikan. Bandung: PT Remaja Roesdakarya.

William, R., \& Jacson, Z. 2006. Instructional classroom; Learning environments; sociocultural theory. [Versi elektronik]. International Journal of Science and Mathemathics Education, 4, 7, 25-33.

De Porter De Porter, B \& Hernacki, M. (2006). Quantum learning. Bandung: PT Mizan Pustaka

Suharsimi, A. (2002). Dasar-dasar evaluasi pendidikan. Jakarta : Bumi Aksara. 